\title{
Complex lethal osteochondrodysplasia
}

INSERM

\section{Source}

INSERM. (1999). Orphanet: an online rare disease and orphan drug data base. Complex lethal osteochondrodysplasia. ORPHA:457378

A rare, genetic, primary bone dysplasia with decreased bone density characterized by fetal lethality, severe hypomineralization of the entire skeleton, barrel shaped thorax with short ribs, multiple intrauterine fractures of ribs and long bones, ascites, pleural effusion, and ventriculomegaly. Variable cong enital developmental anomalies affecting the brain, lungs, and kidneys have also been associated. 